\title{
The Effects of Fasting and Feeding on Preproinsulin Messenger RNA in Rats
}

\author{
Stephen J. Giddings, John Chirgwin, and M. Alan Permutt, Departments of \\ Medicine, Anatomy, and Neurobiology, Washington University School of \\ Medicine, St. Louis, Missouri 63110
}

\begin{abstract}
A B S T RAC T The purpose of these experiments was to determine whether alterations in preproinsulin messenger (m)RNA activity could account for changes in insulin biosynthesis during fasting and refeeding. Rats were fasted $4 \mathrm{~d}$ and then fed for $6,8,24$, or $48 \mathrm{~h}$. With fasting, body weight decreased $25 \%$, plasma glucose decreased from 6.1 to $2.2 \mathrm{mM}$, and pancreatic insulin content fell to $40 \%$ that of fed animals. Islet RNA decreased to $50 \%$ and protein to $55 \%$ that of control animals, while islet DNA content remained unchanged. After $6 \mathrm{~h}$ of refeeding, islet RNA content increased and was not significantly different from controls.
\end{abstract}

Total islet and preproinsulin mRNA activity was estimated with an mRNA-dependent wheat germ cell-free protein synthesizing system. Preproinsulin and total protein synthesis was linearly dependent upon added RNA at concentrations up to $3 \mu \mathrm{g}$. Preproinsulin was identified by its mobility on SDS polyacrylamide gel electrophoresis and by hybrid arrested translation of preproinsulin mRNA. After an 18-h fast, islet mRNA activity decreased 33\%; after $4 \mathrm{~d}$ mRNA activity decreased to $66 \%$ below that of control fed animals. Preproinsulin mRNA activity was decreased, but to a lesser extent, accounting for $20 \%$ of total islet protein in fed animals and $46 \%$ in the 4 -d fasted animals. Total mRNA activity returned to control values after $8 \mathrm{~h}$ of refeeding and increased to $150 \%$ of controls at 24 and $48 \mathrm{~h}$. Preproinsulin mRNA activity increased more rapidly on refeeding. By $8 \mathrm{~h}$ it was $160 \%$ of controls.

This work was presented in part in 1980 at the 40th Annual Meeting of the American Diabetes Association in Washington, D. C.

Dr. Giddings is the recipient of a National Research Service Award (AM-07120) from the National Institutes of Arthritis, Metabolic, and Digestive Diseases. Dr. Permutt is currently a recipient of a U. S. Public Health Service Research Career Development Award K04-00033. Please address reprint requests to him.

Received for publication 30 June 1980 and in revised form 23 October 1980.
To determine whether changes in preproinsulin mRNA activity were associated with changes in the amount of preproinsulin mRNA, nucleic acid hybridization analysis was performed. Pancreatic RNA from fed and fasted animals was electrophoresed on agarose gels, transferred to diazophenylthio paper, and hybridized to ${ }^{32} \mathrm{P}$-labeled preproinsulin complementary (c)-DNA. This analysis demonstrated that changes in mRNA activity were associated with changes in the amount of hybridizable mRNA present. These studies are the first to demonstrate alterations of preproinsulin mRNA under any conditions, and the changes correlate with alterations in rates of insulin biosynthesis.

\section{INTRODUCTION}

The steps involved in synthesis of the polypeptide hormone insulin have been studied extensively $(1,2)$. Synthesis of preproinsulin on membrane bound polysomes is followed rapidly by cleavage of the "pre" portion $(2-4)$, then proinsulin is cleaved to insulin within the cisternae of the rough endoplasmic reticulum (5). Recombinant DNA techniques have recently provided much information about the structure of insulin mRNA and the insulin gene $(6,7)$. In spite of this extensive knowledge of the structure of the messenger (m)RNA and sequential biosynthetic steps, very little is known about regulation of expression of the insulin gene. When mammalian islets are incubated in vitro, glucose is a potent stimulator of insulin biosynthesis $(8,9)$. Previous studies had shown that the number of ribosomes active in protein synthesis increased two- to fourfold when glucose in the incubation media was raised from 2 to $20 \mathrm{mM}$. This was the result of an increase in the rate of initiation (10). Indirect evidence from experiments using RNA and protein synthesis inhibitors suggested that the specific stimulation of insulin biosynthesis by glucose also involved the increased synthesis of insulin mRNA $(10,11)$.

Nutritional changes alter the rate of insulin biosynthesis as well as secretion in experimental animals. 
Tjioe and Bouman (12) and Bone and Howell (13) found that islets from fasted rats had an impaired insulin biosynthetic response to glucose when measured in vitro. These data suggested that the decrease in pancreatic insulin content seen with starvation $(14,15)$ was produced by decreased rates of synthesis. To determine whether changes in insulin biosynthesis are modulated at the level of mRNA, we have compared rat islet DNA, RNA, and protein content with islet mRNA translatable in a cell-free system. There was a marked reduction of insulin content on starvation, which was preceded by a reduction of islet RNA. Translational activity of total islet and preproinsulin mRNA was reduced by starvation and increased to greater than that of fed controls on refeeding. Preproinsulin mRNA levels, measured by RNA complementary (c)DNA hybridization, paralleled changes in mRNA activity.

\section{METHODS}

Animals. All experiments were carried out on SpragueDawley rats weighing $200 \mathrm{~g}$ (Eldridge Laboratory Animals, St. Louis, Mo.). These animals were fed Purina Rat Chow (Ralston Purina Co., St. Louis, Mo.) ad lib. until the time of experiments.

Preparation of rat pancreatic islets. Islets of Langerhans were prepared as described by Lacy and Kostianovsky (16) with the following modifications: Hanks' buffer was made 25 $\mathrm{mM}$ with HEPES at $\mathrm{pH}$ 7.4. Pancreatic digests were filtered through nylon mesh (Nitex, 80 mesh) after washing and centrifuged through discontinuous Ficoll (Sigma Chemical Co., St. Louis, Mo.) gradients according to the method of Scharp et al. (17). Islets were then collected from the interfaces in the Ficoll-Hanks'-HEPES gradients, washed twice with Hanks'HEPES buffer, and gently pelleted by centrifugation at $200 \mathrm{~g}$ for $1 \mathrm{~min}$ at $20^{\circ} \mathrm{C}$. All glassware was siliconized.

Preparation of RNA. Islets were dissolved in $4 \mathrm{M}$ guanidinium thiocyanate (Fluka A. G., Basel, Switzerland), sodium citrate, $25 \mathrm{mM}, \mathrm{pH} 7.0,0.1 \mathrm{M}$ 2-mercaptoethanol, $0.33 \%$ Sigma anti-foam A. RNA was isolated by ultracentrifugation through cesium chloride (Fluka A. G.) as described by Glisin et al. (18). Pelleted material was washed twice with $95 \%$ ethanol at $-20^{\circ} \mathrm{C}$ and then dissolved in sterile water. Ratios of absorbance at 260 and $280 \mathrm{~nm}$ were $>2.0$. RNA was precipitated overnight at $-20^{\circ} \mathrm{C}$ with $2 \mathrm{vol}$ of $95 \%$ ethanol and 0.1 vol of $2 \mathrm{M}$ potassium acetate. Precipitated material was collected by centrifugation at $12,000 \mathrm{~g}, 2^{\circ} \mathrm{C}, 30 \mathrm{~min}$, then dissolved in sterile water at a concentration of $0.5 \mu \mathrm{g} / \mu \mathrm{l}$ and stored at $-70^{\circ} \mathrm{C}$ until use. Approximately $50 \mu \mathrm{g}$ of RNA was obtained from isolated islets pooled from four- to five rats. All solutions and glassware used were either autoclaved for $1 \mathrm{~h}$ or treated with $0.2 \%$ diethyl pyrocarbonate (Sigma Chemical Co.) or both.

Translation analysis of rat islet RNA. RNA was translated in a cell-free system derived from wheat germ, prepared according to the method of Roberts and Paterson (19), except that the S-30 extract was not preincubated before freezing. Reaction mixtures, $25 \mu$ l, contained 19 unlabeled amino acids at $40 \mu \mathrm{M}\left[{ }^{35}\right.$ S $]$ methionine $10 \mu \mathrm{Ci}, \sim 1,000 \mathrm{Ci} / \mathrm{mmol} \mathrm{sp}$ act (Amersham/Searle Corp., Arlington Heights, Ill.), potassium acetate $(80 \mathrm{mM})$, magnesium acetate $(2.5 \mathrm{mM})$, ATP $(1 \mathrm{mM})$, guanosine triphosphate (GTP) $(0.4 \mathrm{mM})$, creatine phosphate $(8 \mathrm{mM})$, creatine kinase $(8 \mu \mathrm{g} / \mathrm{ml}, 155 \mathrm{U} / \mathrm{mg}), 4,2$-hydroxyethyl-1-piperazine-ethane sulfonic acid $(25 \mathrm{mM}, \mathrm{pH} 6.0)$, spermidine $(20 \mu \mathrm{M})$, dithiothreitol $(2 \mathrm{mM})$, benzamidine $(1 \mathrm{mM})$, and $5 \mu \mathrm{l}$ of S-30.

Incubations were performed at $31^{\circ} \mathrm{C}$ for $90 \mathrm{~min}$. Total protein synthesis was determined on $5 \mu$ l aliquots by the method of Manns and Novelli (20). $10 \mu \mathrm{l}$ aliquots of translation mix dissolved in $10 \%$ SDS 2-mercaptoethanol $0.5 \mathrm{M}$ Tris, $\mathrm{pH}$ 6.8 , and $15 \%$ glycerol were analyzed on $15 \%$ acrylamide slab gels with the discontinuous buffer system of Laemmli as described (21). Autoradiographs were performed on the dried gels and the relative amounts of radiolabeled material in each band was determined by densitometric analysis in a Gilford spectrophotometer (Gilford Instrument Laboratories, Oberlin, Ohio). Molecular weight markers used (Sigma Chemical Co.) were cytochrome $c(12,300 \mathrm{~mol} \mathrm{wt})$, myoglobin $(17,400$ mol wt), chymotrypsinogen $(25,600 \mathrm{~mol} w \mathrm{wt}$ ), ovalbumin $(43,000 \mathrm{~mol} \mathrm{wt})$, and B-chain of insulin $(3,500 \mathrm{~mol} \mathrm{wt})$. Bovine proinsulin $(9,000 \mathrm{~mol} \mathrm{wt})$ was obtained from Dr. Ronald Chance (Eli Lilly and Company, Indianapolis, Ind.).

Hybridization arrest of cell-free translation. Hybridarrested translation was performed as described by Paterson et al. (22). The plasmid peRI354 containing a nearly full-length cloned copy of rat preproinsulin I cDNA was used. This probe has been demonstrated to bind to rat insulin II as well as insulin I DNA (23). The plasmid was linearized with EcoRI endonuclease, extracted with phenol and precipitated with 2 vol 95\% ethanol and dissolved in sterile water. After heat denaturation of the double stranded probe at $100^{\circ} \mathrm{C}, 10 \mathrm{~min}$, followed by quick cooling, varying concentrations of the plasmid were incubated for $4 \mathrm{~h}$ at linearly decreasing temperatures from 55 to $45^{\circ} \mathrm{C}$ with $5 \mu \mathrm{g}$ of rat RNA in $80 \%$ formaldehyde ( $\mathrm{vol} / \mathrm{vol})$, sodium chloride $(0.4 \mathrm{M})$, and 4-piperazine diethane sulfonic acid ( $10 \mathrm{mM}, \mathrm{pH} 6.4$ ) in $25 \mu$ l. Each sample was diluted with $200 \mu \mathrm{l}$ of sterile water containing $25 \mu \mathrm{g}$ of phenol-extracted wheat germ transfer RNA (Sigma Chemical Co.). Each aliquot was divided equally. One-half was heated to $100^{\circ} \mathrm{C}$ for $1 \mathrm{~min}$, both aliquots were ethanol precipitated, and then dissolved in $10 \mu \mathrm{l}$ of sterile water and translated in the wheat germ translation system.

RNA, DNA, and protein determinations of isolated islets. Aliquots of $\sim 50$ islets counted under a dissecting microscope were pipetted into $500 \mu \mathrm{l}$ microfuge tubes and lyophilized. Samples were then dissolved in $5 \mu \mathrm{l}$ of cold $0.2 \mathrm{~N}$ perchloric acid, precipitates were centrifuged at $12,000 \mathrm{~g}, 5 \mathrm{~min}, 4^{\circ} \mathrm{C}$, and the supernatant fluids were discarded. The precipitates were dissolved in $20 \mu \mathrm{l}$ of $0.3 \mathrm{~N}$ potassium hydroxide. $2 \mu \mathrm{l}$ of each sample was removed for protein determinations, samples were heated for $1 \mathrm{~h}$ at $37^{\circ} \mathrm{C}$, re-precipitated with $12.5 \mu \mathrm{l}$ of 0.2 $\mathrm{N}$ perchloric acid and washed twice with $25 \lambda 0.2 \mathrm{~N}$ TCA RNA was determined from the absorbance at $260 \mathrm{~nm}$ of the supernatant and washings. Dried pellets were then reacted with diaminobenzoic acid and DNA concentrations determined fluorometrically as described (24). The 2- $\mu$ l samples for protein determinations were precipitated and dissolved in solutions containing fluorescein and protein concentrations determined fluorometrically as described (25).

Pancreatic insulin and DNA determinations. Sections of pancreas were frozen at $-70^{\circ} \mathrm{C}$ and stored. They were then extracted with acid alcohol and insulin was determined on the acid alcohol extract by standard radioimmunoassay. Acid alcohol-insoluble material was precipitated with $0.4 \mathrm{~N}$ perchloric acid and DNA concentrations determined with diphenylamine as described (26).

Serum glucose determinations. Samples of rat blood obtained by intracardiac puncture were allowed to coagulate, serum was collected and stored at $-70^{\circ} \mathrm{C}$. Glucose was determined by standard photofluorometric assay (27).

Hybridization analysis. 200-g rats were either fed or starved for $4 \mathrm{~d}$. Total pancreas was excised, weighed, and 
homogenized at highest speed with a polytron in $10 \mathrm{ml}$ of $4 \mathrm{M}$ guanidinium thiocyanate containing $25 \mathrm{mM}$ sodium citrate, pH 7,0.1 M 2-mercaptoethanol, 0.33\% Sigma anti-foam A. Samples were then precipitated by adding $1 / 40 \mathrm{vol}$ of $1 \mathrm{M}$ acetic acid and $3 / 4$ vol of $95 \%$ ethanol, chilled at $-20^{\circ} \mathrm{C}$ overnight. The material was pelleted by centrifugation at $6,000 \mathrm{~g}$ for $10 \mathrm{~min}$ at $-20^{\circ} \mathrm{C}$. Only material that formed a firm pellet was kept and the rest of the material was aspirated. The pellets were redissolved in $8 \mathrm{M}$ guanidinium hydrochloride made to $\mathrm{pH} 7$ with $25 \mathrm{mM}$ sodium citrate and $0.1 \mathrm{M}$ in 2-mercaptoethanol. Samples were precipitated again by adding $1 / 40 \mathrm{vol}$ $1 \mathrm{M}$ acetic acid and $1 / 2 \mathrm{vol}$ of $95 \%$ ethanol. Reprecipitation in $8 \mathrm{M}$ guanidinium hydrochloride was performed a total of four times. The samples were then dissolved in $\sim 2 \mathrm{ml} \mathrm{H}_{2} \mathrm{O}$ and precipitated with $0.1 \mathrm{vol} 2 \mathrm{M}$ sodium potassium acetate, $\mathrm{pH} 5$, and 2 vol $95 \%$ ethanol at $-20^{\circ} \mathrm{C}$ overnight. RNA concentrations were determined by absorbance at $260 \mathrm{nM}$. In addition, the amount of RNA, DNA, and protein in each total pancreas was determined from a $100-\mu l$ aliquot of the original guanidine thiocyanate pancreatic homogenate. Total pancreatic RNA from each rat was glyoxalated according to the procedure of McMaster and Carmichael (28). Samples were electrophoresed on $2 \%$ agarose gels (treated with $0.1 \%$ diethyl pyrocarbonate before they were poured). Gels were $0.3 \mathrm{~cm}$ thick and $12 \times 14 \mathrm{~cm}$. All samples were run at $40 \mathrm{~V}$ at room temperature for $\sim 4 \mathrm{~h}$. Molecular weight markers on gels included 28 and 18S ribosomal RNA, plasmid pCRI354 and the 354 base insulin cDNA sequence from the plasmid. RNA run on gels was then transferred to diazophenylthio (DPT) paper in the following manner: RNA in gels was partially hydrolysed by incubating the gel in $50 \mathrm{mM}$ sodium acetate for $\sim 0.5 \mathrm{~h}$ at room temperature. The gel was then washed twice for $15 \mathrm{~min}$ periods each in $200 \mathrm{mM}$ sodium acetate at $\mathrm{pH}$ 4. RNA was then transferred from the gel using $200 \mathrm{mM}$ sodium acetate as described by Wahl et al. (29) to DPT paper using $200 \mathrm{mM}$ sodium acetate, $\mathrm{pH} \mathrm{4}$, as the transfer buffer The RNA bound to DPT paper was then prehybridized by placing the paper in a heat-sealed plastic bag with buffer containing $50 \% \mathrm{vol} / \mathrm{vol}$ formamide, $0.8 \%$ sodium chloride, 50 $\mathrm{mM}$ potassium phosphate, $\mathrm{pH} 6.5,0.02 \%$ polyvinylpyrrolidone, $0.02 \%$ Ficoll, $0.02 \%$ bovine serum albumin, 250

${ }^{1}$ Abbreviation used in this paper: DPT, diazophenylthio. $\mu \mathrm{g}$ salmon sperm DNA, $0.1 \%$ SDS, and $1 \%$ glycine. Air bubbles were extruded from the bag and the bag was sealed with heat and incubated at $42^{\circ} \mathrm{C}$ for $\sim 24 \mathrm{~h}$. Hybridization was performed with the excised insert from the rat preproinsulin I cDNA plasmid pCRI354 which was labeled by nick translation (30) to $\sim 3 \times 10^{8} \mathrm{cpm} / \mu \mathrm{g}$ sp act. Hybridization buffer was identical to prehybridization buffer with the following exceptions. Glycine was omitted from the hybridization buffer which was made $20 \%$ with dextran sulfate T 500,000 mol wt. ${ }^{32} \mathrm{P}$-cDNA in $10 \mathrm{ml}$ hybridization buffer was placed in the bag, the bag was sealed and incubated at $42^{\circ} \mathrm{C}$ for $24 \mathrm{~h}$. Paper was then washed twice for $15 \mathrm{~min}$ each in $360 \mathrm{mM}$ sodium chloride, $20 \mathrm{mM} \mathrm{Na}^{2} \mathrm{PO}_{4}$, pH 7, $2 \mathrm{mM}$ EDTA, and $0.1 \%$ SDS at room temperature. Two $30-\mathrm{min}$ washes containing 18 $\mathrm{mM}$ sodium chloride, $1 \mathrm{mM}$ sodium phosphate, $\mathrm{pH} 7,0.1 \%$ $\mathrm{SDS}$, and $0.1 \mathrm{mM}$ EDTA were performed at $58^{\circ} \mathrm{C}$. The paper was then air dried and autoradiographs were performed. After autoradiographs were performed, the hybridized bands were cut from DPT paper and counted. Background was estimated from several equal sized pieces of DPT paper cut from elsewhere on the hybridized paper.

\section{RESULTS}

Effects of fasting and refeeding on islet DNA, RNA, and protein content. Rats were fasted for $4 \mathrm{~d}$ and then refed for 24 or $48 \mathrm{~h}$. Changes in body weight, plasma glucose, and pancreatic insulin content are shown in Table I. Body weight decreased $25 \%$ on fasting, and increased rapidly on refeeding. A great portion of these rapid changes in weight can be attributed to stomach and intestinal contents (31). Glucose fell from 6.1 to $2.2 \mathrm{mM}$, a concentration that has been shown to allow very low levels of insulin biosynthesis in islets incubated in vitro (9). Refeeding restored plasma glucose levels to normal within $48 \mathrm{~h}$. Pancreatic insulin content fell to $40 \%$ that of fed animals after $4 \mathrm{~d}$ of fasting as previously noted $(14,15)$.

The effects of fasting and refeeding on DNA, RNA, and protein content of isolated rat islets is seen in

TABLE I

Effects of Fasting and Refeeding on Body Weight, Plasma Glucose, and Pancreatic Insulin Content

\begin{tabular}{lccc}
\hline & Body weight & $\begin{array}{c}\text { Plasma } \\
\text { glucose }\end{array}$ & $\begin{array}{c}\text { Pancreatic } \\
\text { insulin content }\end{array}$ \\
\hline & $g$ & $m M$ & $\begin{array}{c}\mu g \text { insulin/ } \\
m g D N A\end{array}$ \\
& & & $37.4 \pm 5.8 \ddagger \S$ \\
Fed & $199.0 \pm 4.0^{*}$ & $6.1 \pm 0.5 \ddagger$ & \\
Fasted, $4 \mathrm{~d}$ & $150.5 \pm 3.8^{*} \ddagger$ & $2.2 \pm 0.5 \ddagger \S$ & $15.0 \pm 1.6 \ddagger \S$ \\
Fasted, $4 \mathrm{~d}$, and refed: & & & \\
$24 \mathrm{~h}$ & $191.0 \pm 3.4^{*}$ & $4.9 \pm 0.4 \ddagger$ & $19.8 \pm 3.3 \ddagger$ \\
$48 \mathrm{~h}$ & $191.0 \pm 4.0^{*}$ & $6.6 \pm 1.1 \ddagger$ & $29.0 \pm 4.2 \ddagger$ \\
\hline
\end{tabular}

The fed animals were fed ad lib. for $6 \mathrm{~d}$ and determinations made. Plasma glucose and pancreatic insulin content measurements were as described in Methods.

$* n=6$, data expressed as mean \pm SEM.

$\ddagger n=5$, data expressed as mean \pm SEM.

$\S$ Significantly less than values for fed animals $(P<0.001)$. 
TABLE II

Effects of Fasting and Refeeding on Rat Pancreatic Islet

Content of DNA, RNA, and Protein

\begin{tabular}{lccc}
\hline & DNA & RNA & Protein \\
\hline & & ng/islet \\
Fed & $21.2 \pm 2.2$ & $121 \pm 11$ & $597 \pm 69$ \\
Fasted, 4 d & $20.8 \pm 3.7$ & $62 \pm 14^{*}$ & $321 \pm 14^{*}$ \\
Fasted, 4 d, and refed, 6 h & $18.9 \pm 0.6$ & $106 \pm 15$ & $242 \pm 19^{*}$ \\
\hline
\end{tabular}

Four groups of rats $(n=6)$ were either fed ad lib., fasted $4 \mathrm{~d}$, or fasted $4 \mathrm{~d}$ and then fed for $6 \mathrm{~h}$ before islets were isolated. DNA, RNA, and protein determinations were made on 50 islets $(n=5)$ from each group as described in Methods. Data are expressed as mean \pm SEM.

$* P<0.05$ (two tailed $t$-test), less than fed values.

Table II. Amount of DNA per islet remained unchanged. RNA content decreased to one-half after $4 \mathrm{~d}$ of starvation. After $6 \mathrm{~h}$ of refeeding, RNA content increased rapidly and was not significantly lower than in fed animals. Total islet protein fell to $54 \%$ of control with fasting, and fell further after $6 \mathrm{~h}$ of refeeding.

Assay of islet and preproinsulin mRNA activity. A wheat germ mRNA-dependent cell-free protein synthesizing system was used as an assay to determine whether altered rates of insulin biosynthesis observed during fasting were reflected in changes of functional insulin mRNA. Since others have noted modulation of different proteins by alterations of conditions of cellfree synthesis, preliminary experiments were performed to determine whether this data reflected insulin mRNA concentration.

Protein synthesis, measured by $\left.{ }^{35} \mathrm{~S}\right]$ methionine incorporation, was linearly dependent upon added islet RNA at concentrations up to $3 \mu \mathrm{g}$ (Fig. 1). Preproinsulin

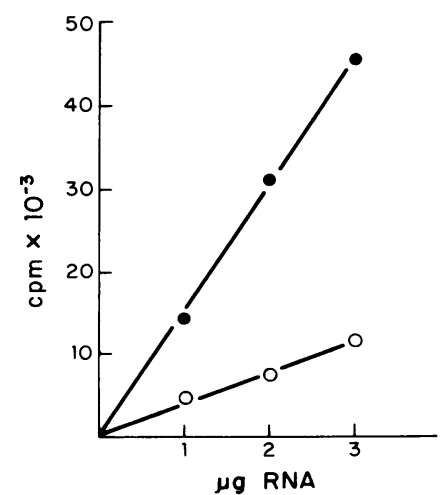

FIGURE 1 Effect of increasing concentration of islet RNA in the wheat germ translation system on synthesis of total islet protein and preproinsulin. RNA was incubated for $90 \mathrm{~min}$ at $31^{\circ} \mathrm{C}$ in a translation mix with $80 \mathrm{mM}$ potassium, $2.5 \mathrm{mM}$ magnesium in $25 \mu \mathrm{l}$ vol. Incorporation of $\left[{ }^{35} \mathrm{~S}\right]$ methionine into total protein $(\bullet)$ and $(\bigcirc)$ preproinsulin were determined as described in Methods. synthesis was quantitated by densitometric tracings of radioautographs obtained from SDS-polyacrylamide gel electrophoresis of labeled products (see below). Preproinsulin synthesis was also directly proportional to added RNA. To determine whether there was a selective effect of alteration of salt concentration on synthesis of preproinsulin, relative to other islet proteins, $\mathrm{K}^{+}$and $\mathrm{Mg}^{++}$concentrations were evaluated (Fig. 2). Incorporation into total protein and preproinsulin was optimal at $80 \mathrm{mM} \mathrm{K}$, and decreased proportionately with increasing $\mathrm{K}^{+}$. Similarly translation of total islet protein and preproinsulin was optimal at the same $\mathrm{Mg}^{++}$concentration $(2.5 \mathrm{mM})$.

Translation products were characterized by SDSpolyacrylamide gel electrophoresis and autoradiography of $\left[{ }^{35}\right.$ S $]$ methionine-labeled proteins (Fig. 3). The prominent protein band $(11,500 \mathrm{~mol} \mathrm{wt})$ migrating between cytochrome $c$ and proinsulin standards had been identified as rat preproinsulins I and II, the major products and cell-free translation of rat islet mRNA (32, 33). They have been isolated and found by microsequencing to contain 24 extra amino acids on the amino terminus of proinsulin. This has been confirmed by sequencing of the cloned $\mathrm{cDNA}$ to rat preproinsulin I and II mRNA $(34,35)$. Preproinsulins I and II mRNA together comprised about $20 \%$ of the total islet messenger activity estimated by densitometric tracings of the radioautographs. Proteins up to $65,000 \mathrm{~mol}$ wt were also translated indicating successful isolation of larger islet mRNA than previously reported $(32,33)$.

Because we wanted to measure preproinsulin mRNA activity, further characterization of the cell-free translation products was obtained with the hybrid-arrested translation method of Paterson et al. (22). Rat islet RNA was hybridized with the cloned plasmid pcRI354 containing an almost full-length copy of rat preproinsulin I cDNA. This cDNA binds to both rat insulin I and II genes (23) and should inhibit translation of both mRNA since the homology is $>90 \%$. After hybridization, the samples were divided; one-half was heat de- 

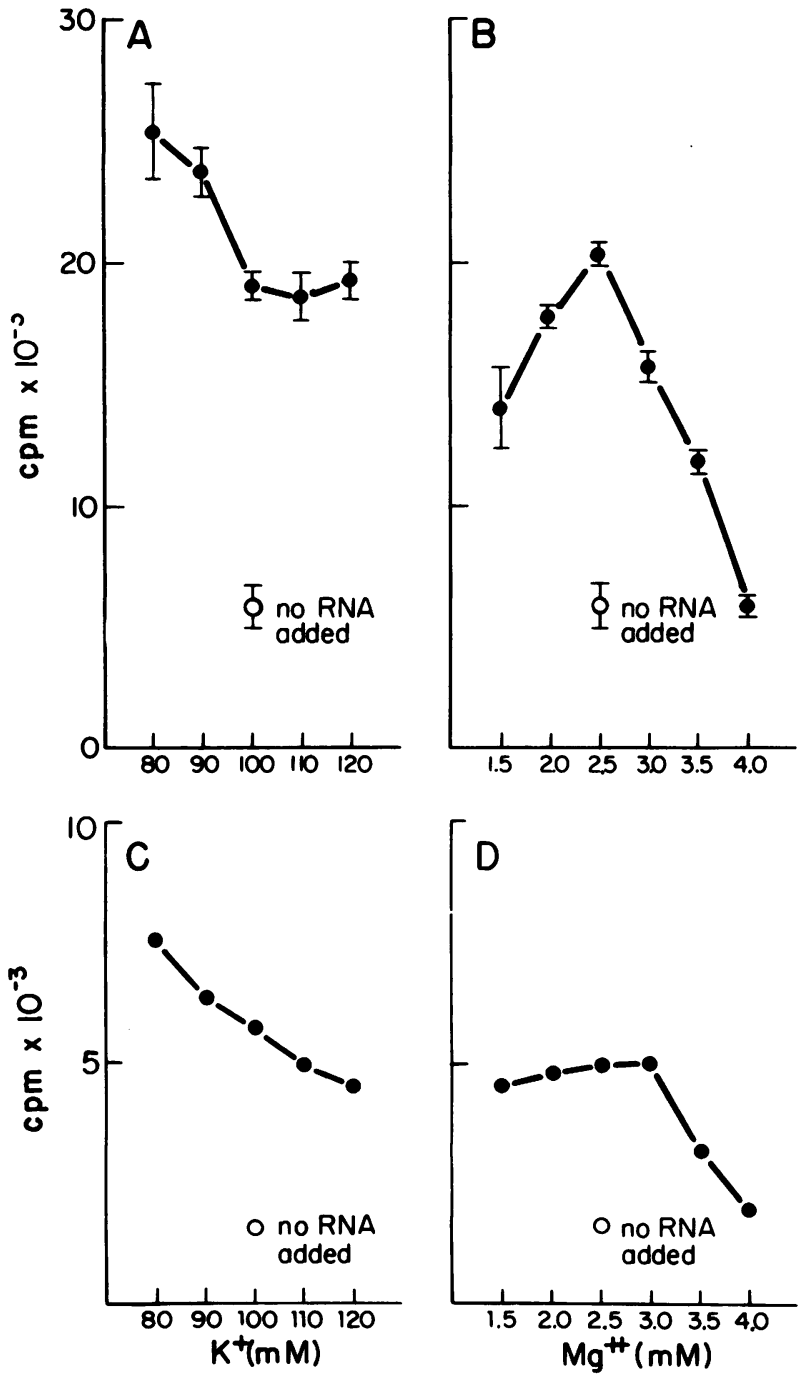

FIGURE 2 Effects of potassium and magnesium concentration on cell-free synthesis of total islet protein and preproinsulin. In each experiment $2 \mu \mathrm{g}$ of RNA was translated. (A) Effect of potassium concentration, and (B) magnesium concentration on total islet protein synthesis; (C) effect of potassium, and (D) of magnesium on preproinsulin synthesis. (A) and (C), $\mathrm{Mg}^{++}=2.5 \mathrm{mM}$; (B) and (D), $\mathrm{K}^{+}=100 \mathrm{mM}$.

natured to remove hybridized DNA as a treatment control, and both halves were translated (Fig. 4). Since hybridization was for $4 \mathrm{~h}$, there was some decrease in the quality of the translation products. Densitometric tracings of the gel, however, showed that $1 \mu \mathrm{g}$ of plasmid specifically inhibited translation of the $11,500 \mathrm{~mol}$ wt band relative to other islet proteins. These data demonstrated that translational analysis of total islet RNA was a reasonable way of defining levels of total islet and preproinsulin mRNA activity.

Effects of fasting and refeeding on islet mRNA activity. After $18 \mathrm{~h}$ of fasting there was a significant re- duction in islet mRNA activity compared to that of fed controls (Table III). Rats fasted $4 \mathrm{~d}$, or fasted $4 \mathrm{~d}$ and then refed 8,24 , or $48 \mathrm{~h}$ were studied with a different wheat germ preparation at a later time. Fasting produced a decrease in total islet mRNA activity to onethird that in control animals (Table III and Fig. 5). Preproinsulin mRNA activity also decreased, but to a lesser extent than did total mRNA activity. Refeeding produced a rapid restoration of total islet mRNA activity to control values by $8 \mathrm{~h}$, and to greater than control at $24 \mathrm{~h}$. This increased mRNA activity was still present at $48 \mathrm{~h}$. Preproinsulin mRNA activity increased to $160 \%$ of control levels within $8 \mathrm{~h}$ of refeeding (Fig. 5), and remained at that level over the ensuing $2 \mathrm{~d}$.

Hybridization analysis of preproinsulin mRNA. To determine whether changes in translational activity were the result of changes in the number of preproinsulin mRNA sequences, as opposed to alterations of the mRNA, further studies were carried out to measure preproinsulin mRNA in fed and starved rats. Rats were fed or starved for $4 \mathrm{~d}$. DNA content of total pancreas remained unchanged during the starvation period, while RNA content decreased $\sim 30 \%$. Pancreatic RNA

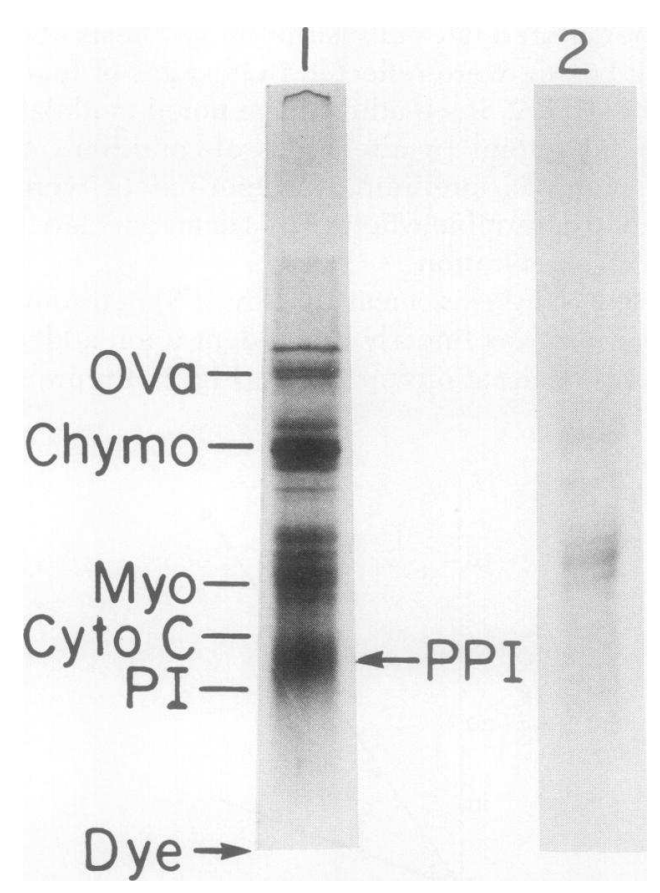

FIGURE 3 Radioautographs of ${ }^{[35}$ S $]$ methionine-labeled translation products directed by rat islet RNA. Aliquots (10 $\mu$ ) of the translation mixtures were electrophoresed on $15 \%$ SDS-polyacrylamide gels, fixed, and the gels stained, dried, and exposed to x-ray film for $4 \mathrm{~d}$ as described in Methods. Ova, ovalbumin (45,000 mol wt); Chymo, chymotrypsinogen (37,000 mol wt); Myo, myoglobin (17,500 mol wt); CYTO, cytochrome $c(12,000 \mathrm{~mol} \mathrm{wt}) ; \mathrm{PI}$, bovine proinsulin $(9,000$ mol wt). Lane 1, plus islet mRNA (2 $\mu \mathrm{g})$; lane 2 , minus mRNA. 


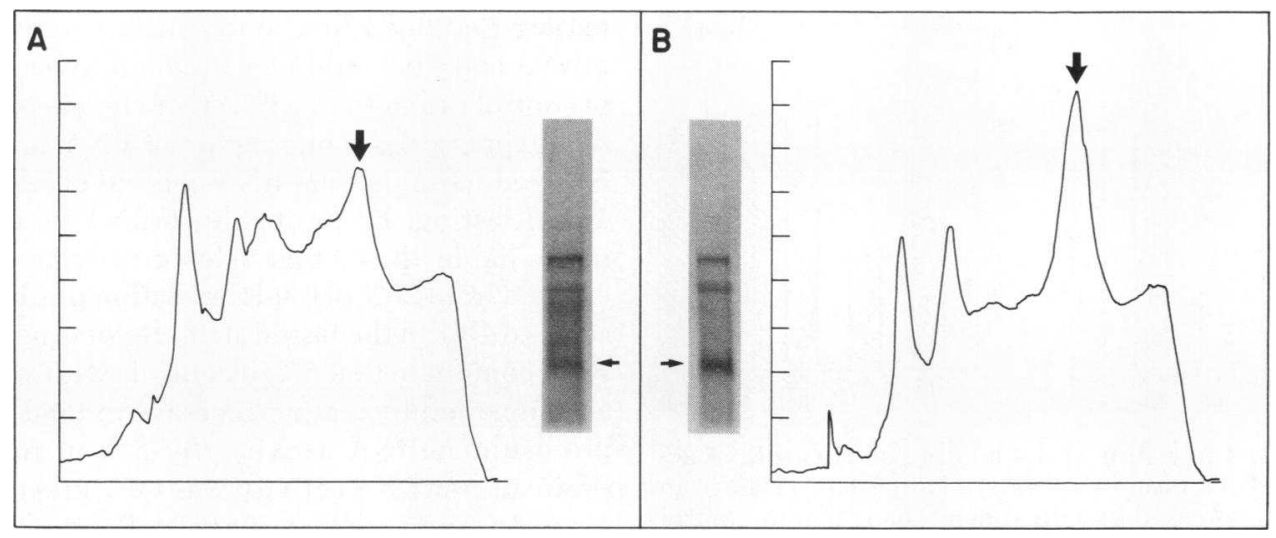

FIGURE 4 Autoradiograph of SDS gel of translation products of hybrid-arrested translation. Pancreatic RNA (5 $\mu \mathrm{g}$ ) was hybridized in $80 \%$ formamide, $0.4 \mathrm{M} \mathrm{NaCl}, 0.04 \mathrm{M} \mathrm{4,2-hydroxyethyl-1-}$ piperazine-ethane sulfonic acid for $4 \mathrm{~h}$ at constantly decreasing temperatures from 55 to $45^{\circ} \mathrm{C}$, with $1 \mu \mathrm{g}$ of the plasmid pCRI354 which contains an almost complete copy of rat preproinsulin I cDNA. The sample was diluted with $50 \mu \mathrm{l}$ of wheat germ transfer RNA in $200 \mu \mathrm{l} \mathrm{H}_{2} \mathrm{O}$, divided into equal aliquots. One was heated to $100^{\circ} \mathrm{C}$ for $60 \mathrm{~s}$, and both were precipitated with 2 vol of $95 \% \mathrm{ETOH}$ and 0.1 vol $2 \mathrm{M}$ KOAc, dissolved in $\mathrm{H}_{2} \mathrm{O}(10 \lambda)$ and added to a cell-free translation system as described. (A) hybrid arrested mRNA (5 $\mu$ g islet RNA plus $1 \mu \mathrm{g}$ pCRI354, unheated); (B) heat-melted control. Densitometric tracings of each autoradiograph are displayed. Arrows depict the 11,500 mol wt preproinsulin I and II.

from fed and fasted animals was electrophoresed, transferred to filters, and hybridized with ${ }^{32} \mathrm{P}$-rat preproinsulin I cDNA. A representative radiograph from these experiments is shown in Fig. 6. Pancreatic RNA from fed rats (lanes 1 and 2) contained more preproinsulin mRNA than RNA obtained from starved rats (lanes 3 and 4). These data also confirm that rat preproinsulin
mRNA is $\sim 525$ bases in length, 300 bases are required to code for preproinsulin. The autoradiograph also shows that there is no change in the size of preproinsulin mRNA on fasting. After a radioautograph of the gel was obtained, the filters were counted. ${ }^{32} \mathrm{P}$-preproinsulin cDNA hybridized to RNA from three fed animals was $584 \pm 92 \mathrm{cpm}$ (mean \pm range of three determina-

TABLE III

Effect of Fasting and Refeeding on Rat Pancreatic Islet mRNA Activity

\begin{tabular}{lccc}
\hline & \multicolumn{3}{c}{ mRNA activity } \\
\cline { 2 - 4 } & Total & ppI* $^{*}$ & ppI/total $\times 100$ \\
\hline & & $c p m \times 10^{-3 / \mu g ~ R N A ~}$ \\
Experiment 1 & & \\
$\quad$ Fed & $13.6 \pm 0.4$ & $2.7 \pm 0.1$ & 19.9 \\
Fasted, 18 h & $8.8 \pm 0.9 \ddagger$ & $1.9 \pm 0.2 \ddagger$ & 21.6 \\
Experiment 2 & & & \\
Fed & $75.1 \pm 4.1$ & $15.1 \pm 0.8$ & 20.1 \\
Fasted, 4 d & $25.7 \pm 0.7 \ddagger$ & $11.8 \pm 0.4 \ddagger$ & 45.9 \\
Fasted, 4 d, and refed at: & & & \\
8 h & $80.6 \pm 1.2$ & $25.0 \pm 0.4$ & 31.0 \\
24 h & $113.7 \pm 1.5$ & $22.8 \pm 0.3$ & 20.1 \\
48 h & $109.8 \pm 3.8$ & $22.0 \pm 0.8$ & 20.0 \\
\hline
\end{tabular}

Rats in groups of six each were fed, fasted, or fasted and refed as indicated. Pancreases were pooled, islets prepared, RNA isolated and translated as described in Methods. Preproinsulin (ppI) mRNA activity was calculated from densitometric tracings of SDS-gel radioautographs. Each RNA sample was translated three times and given as mean $\pm S E M$.

* ppI, preproinsulin I.

$\ddagger$ Significantly different from fed rats $(P<0.001)$. 

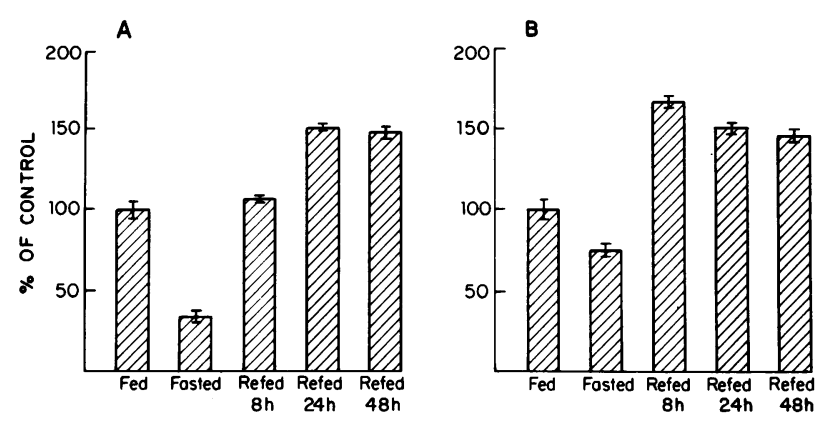

FIGURE 5 Effect of fasting and refeeding on islet mRNA activity contained in rat pancreas islets of Langerhans. Data from Table III are expressed as percentage change from control values. A, total; B, preproinsulin.

tions), three fasted $274 \pm 38$, and three refed $919 \pm 277$. This suggested that the changes in functional preproinsulin mRNA observed with fasting were associated with changes in the amount of mRNA present under these conditions.

\section{DISCUSSION}

These studies demonstrated that a rapid, coordinated total cellular response to starvation and refeeding occurred in rat pancreatic islets. Along with decreased total islet protein and insulin content, functional mRNA declined rapidly in the postabsorptive period. After 18 $\mathrm{h}$ of fasting (Table III) islet messenger activity declined $\sim 35 \%$, and preproinsulin mRNA declined in parallel. Over the next $78 \mathrm{~h}$ of fasting, mRNA activity continued to decline, although at a slower rate, to a level approxi-

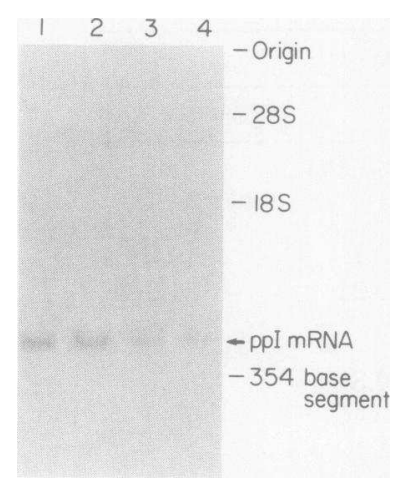

Figure 6 Pancreatic RNA from fed and fasted animals hybridized to ${ }^{32} \mathrm{P}$-rat preproinsulin cDNA. RNA $(20 \mu \mathrm{g})$ was treated with glyoxal (1 M), electrophoresed on $2 \%$ agarose gels, transferred to DPT paper, hybridized to ${ }^{32} \mathrm{P}-$ rat preproinsulin cDNA. RNA $(20 \mu \mathrm{g})$ was treated with glyoxal (1 M), electrophoresed on $2 \%$ agarose gels, transferred to DPT paper, hybridized to ${ }^{32} \mathrm{P}$-preproinsulin cDNA, and a radioautograph obtained as described in Methods. Exposure time was $3 \mathrm{~d}$. Preproinsulin mRNA in RNA $(20 \mu \mathrm{g})$ from fed animals (lanes 1 and 2) compared to that in RNA $(20 \mu \mathrm{g})$ from 4-d fasted animals (lanes 3 and 4). mately one-third that found in fed controls. Absolute mRNA activity could be estimated to be as low as $15 \%$ of control rather than $33 \%$, since the messenger activity was expressed per microgram of RNA, and there was a $50 \%$ reduction in total RNA content of islets during the $4 \mathrm{~d}$ of fasting. Preproinsulin mRNA was shown to be more stable than other islet messengers since it increased from $20 \%$ of total translation products in the fed state, to $46 \%$ in the fasted state. Refeeding restored islet RNA content to that of fed controls within $6 \mathrm{~h}$. This was accompanied by a rapid increase in total islet and preproinsulin mRNA activity. By $8 \mathrm{~h}$ of refeeding, preproinsulin mRNA activity was $60 \%$ greater than in fed controls. An overshoot of total mRNA activity was also observed by $24 \mathrm{~h}$ of refeeding. Therefore, changes in mRNA activity appeared to precede changes in protein and insulin content (Table II).

A quantitative assessment of functional mRNA activity with a cell-free protein synthesizing system requires that the amount of protein product be proportional to the amount of RNA added to the system. Data for Fig. 3 show this to be the case under the conditions of studies. Lomedico, and Saunders (36) studied cellfree translation of fetal bovine pancreatic mRNA and noted selective depression of proinsulin synthesis with increasing mRNA added. It was hypothesized that proinsulin mRNA was translated less efficiently than other messengers and that the specific effects of glucose on proinsulin synthesis in isolated rat islets could simply be due to modulation of translation of existing proinsulin mRNA. The experiments reported here with rat islet RNA, as well as those with cell-free translation of catfish islet mRNA (21) yielded different results than those in which bovine pancreas mRNA was translated. The differences may be explained by use of less than saturating amounts of mRNA; the mRNA source was also from a different species in this report. Because these experiments demonstrate that changes in islet protein synthesis are accompanied by changes in islet insulin mRNA activity they exclude the possibility that regulation of insulin biosynthesis occurs only at the level of translation. These findings do not exclude coexistent changes in rates of translation which may also occur with nutritional changes.

This report is the first of changes of RNA content in pancreatic islets under any experimental conditions. Similar changes in RNA and protein content have been noted in other tissues. A 30-40\% drop in RNA content of liver and jejunal mucosa was observed when rats were starved for $2 \mathrm{~d}$; this correlated with a $40 \%$ diminished protein synthetic rate (31). Liver RNA content varied very rapidly with changes in the nutritional state of experimental animals (37). Fasting or withdrawal of amino acids induced a fall in RNA polymerase activity, a retardation of ribosome subunit maturation, and reduced rates of ribosomal RNA synthesis in 
liver; these changes were rapidly reversed by refeeding (38).

This report is also the first to show a change in islet mRNA under any experimental condition. Reduced insulin biosynthesis observed during starvation correlated with the reduction in preproinsulin mRNA activity. Others have noted that changes in the amount of translatable mRNA parallel changes in protein synthesis, e.g., albumin synthesis in diabetic rats, or rats fed a protein deficient diet. Similar correlations between protein synthesis and mRNA content have also been noted for ovalbumin and conalbumin (39), vitellogenin (40), mouse milk protein (41), and transfer$\operatorname{rin}(42)$.

The physiologic processes by which starvation diminishes insulin biosynthesis and insulin mRNA activity are unknown. Although glucose has demonstrated effects on rates of insulin biosynthesis, other factors may exert modulating effects. For instance, serum $\mathrm{T}_{3}$ levels decrease within 36 to $48 \mathrm{~h}$ of fasting (43) and $T_{3}$ has been shown to affect rates of synthesis of proteins and the levels of their mRNA in target tissues for the hormone (44). Glucocorticoids are elevated during periods of stress or starvation, and they have multiple catabolic effects in many tissues including decreasing rates of protein synthesis, nucleotide and glucose metabolism (45). Other hormones and substrates (e.g., amino acids) as well as serum glucose may affect rates of insulin biosynthesis during fasting and refeeding.

While these studies determine that starvation and refeeding alter pancreatic islet content of preproinsulin mRNA, they do not demonstrate the mechanism by which this event occurs. Alterations of rates of transcription, nuclear processing of mRNA precursors, or increased rates of degradation are all possible sites of regulation. Further studies are required to delineate these mechanisms.

\section{ACKNOWLEDGMENTS}

The authors wish to thank Dr. Jeffrey Gordon for his helpful suggestions in reviewing this paper, Lynda Bogar for excellent technical assistance, and Jane Pace for preparing this manuscript. This work was supported by National Institutes of Health grant AM-16746 and a grant from the St. Louis Diabetic Children's Welfare Association.

\section{REFERENCES}

1. Steiner, D. F. 1976. Errors in insulin biosynthesis. $N$. Engl. J. Med. 294: 952-953.

2. Albert, S. G., and M. A. Permutt. 1979. Proinsulin precursors in catfish pancreatic islets. J. Biol. Chem. 254: 3483-3492.

3. Shields, D., and G. Blobel. 1977. Cell-free synthesis of fish preproinsulin and processing by heterologous mammalian microsomal membranes. Proc. Natl. Acad. Sci. U. S. A. 74: 2059-2063.
4. Permutt, M. A., and A. Routman. 1977. Proinsulin precursors in isolated rat pancreatic islets. Biochem. Biophys. Res. Commun. 78: 855-862.

5. Kemmler, W., J. D. Peterson, A. H. Rubenstein, and D. F. Steiner. 1972. On the biosynthesis, intracellular transport and mechanism of conversion of proinsulin to insulin and C-peptide. Diabetes. 21(Suppl. 2): 572-581.

6. Cordell, B., G. Bell, E. Tischer, F. M. DeNoto, A. Ullrich, R. Pictet, W. J. Rutter, and H. M. Goodman. 1979. Isolation and characterization of a cloned rat insulin gene. Cell. 18: 533-543.

7. Lomedico, P., N. Rosenthal, A. Efstratiadis, W. Gilbert, R. Kolodner, and R. Tizard. 1979. The structural and evolution of the two nonallelic rat preproinsulin genes. Cell. 18: 545-558.

8. Taylor, K. W. 1969. Regulation of Insulin Synthesis. In Progress in Endocrinology. C. Gaul, and F. J. G. Ebling, editors. Excerpta Medica, Amsterdam. 220.

9. Morris, G. E., and A. Korner. 1970. The effect of glucose on insulin biosynthesis by isolated islets of Langerhans of the rat. Biochim. Biophys. Acta. 208: 404-413.

10. Permutt, M. A. 1974. Insulin biosynthesis. IV. Effect of glucose on initiation and elongation rates in isolated rat pancreatic islets. J. Biol. Chem. 249: 2738-2742.

11. Permutt, M. A., and D. M. Kipnis. 1972. Insulin biosynthesis. I. On the mechanism of glucose stimulation. $J$. Biol. Chem. 247: 1194-1199.

12. Tjioe, T. O., and P. R. Bouman. 1976. Effect of fasting on the incorporation of $\left[{ }^{3} \mathrm{H}\right]-\mathrm{L}-$ phenylalanine into proinsulin-insulin and total protein in isolated rat pancreatic islets. Horm. Metab. Res. 8: 261-266.

13. Bone, A. J., and S. L. Howell. 1977. Alterations in regulation of insulin biosynthesis in pregnancy and starvation studied in isolated rat islets of Langerhans. Biochem. J. 166: $501-507$.

14. Best, C. H., R. E. Haist, and J. H. Ridout. 1939. Diet and the insulin content of pancreas. J. Physiol. 97: 107-119.

15. Malaisse, W. J., F. Malaisse-Lagae, and P. H. Wright. 1967. Effect of fasting upon insulin secretion in the rat. Am.J. Physiol. 213: 843-848.

16. Lacy, P. E., and M. Kostianovsky. 1967. Method for the isolation of intact islets of Langerhans from the rat pancreas. Diabetes. 16: 35-39.

17. Scharp, D. W., C. B. Kemp, M. J. Knight, W. F. Ballinger, and P. E. Lacy. 1973. The use of ficoll in the preparation of viable islets of Langerhans from the rat pancreas. Transplantation (Baltimore). 16: 686-689.

18. Glisin, V., R. Crkvenjakov, and C. Byus. 1974. Ribonucleic acid isolated by cesium chloride centrifugation. Biochemistry. 13: 2633-2638.

19. Roberts, B. E., and B. M. Paterson. 1973. Efficient translation of tobacco mosaic virus RNA and rabbit globin $9 S$ RNA in a cell-free system from commercial wheat germ. Proc. Natl. Acad. Sci. U. S. A. 70: 2330-2334.

20. Manns, R. J., and G. D. Novelli. 1961. Measurement of the incorporation of radioactive amino acids into protein. Arch. Biochem. Biophys. 94: 48-53.

21. Permutt, M. A., R. Chyn, and M. Goldford. 1978. Isolation and partial purification of catfish pancreatic islet messenger RNA. Biochemistry. 17: 537-543.

22. Paterson, B. M., B. E. Roberts, and E. L. Kuff. 1977. Structural gene identification and mapping by DNAmRNA hybrid arrested cell-free translation. Proc. Natl. Acad. Sci. U. S. A. 74: 4370-4374.

23. Bell, G. I., W. F. Swain, R. Pictet, B. Cordell, H. M. Goodman, and W. J. Rutter. 1979. Nucleotide sequence of a cDNA clone encoding human preproinsulin. Nature (Lond.) 282: 525-527. 
24. Hinegardner, R. T. 1971. An improved fluorometric assay for DNA. Anal. Biochem. 39: 197-201.

25. Bohlen, P., S. Stein, W. Dairman, and S. Udenfriend. 1979. Fluorometric assay of proteins in the nanogram range. Arch. Biochem. Biophys. 155: 213-220.

26. Shatkin, A. 1969. Fundamental Techniques in Virology. Hebel and Salzman, editors. Academic Press, Inc. New York.

27. Lowry, O., and J. V. Passonneau. 1972. A flexible system of enzymatic analysis. Academic Press, Inc., New York. 1975.

28. McMaster, G. K., and G. G. Carmichael. 1977. Analysis of single- and double-stranded nucleic acids on polyacrylamide and agarose gels by using glyoxal and acridine orange. Proc. Natl. Acad. Sci. U. S. A. 74: 4835-4838.

29. Wahl, G. M., M. Stern, and G. R. Stark. 1979. Efficient transfer of large DNA fragments from agarose gels to diazobenzyloxymethyl-paper and rapid hybridization by using dextran sulfate. Proc. Natl. Acad. Sci. U. S. A. 76: 3683-3687.

30. Rigby, P. W. J., M. Dieckmann, C. Rhodes, and P. Berg. 1977. Labeling deoxyribonucleic acid to high specific activity in vitro by nick translation with DNA polymerase I. J. Mol. Biol. 113: 237-251.

31. McNurlan, M. A., A. M. Tomkins, and P. J. Garlick. 1979 The effect of starvation on the rate of protein synthesis in rat liver and small intestine. Biochem. J. 178: 373-379.

32. Chan, S. J., P. Keim, and D. F. Steiner. 1976. Cell-free synthesis of rat preproinsulins: characterization and partial amino acid sequence determination. Proc. Natl. Acad. Sci. U. S. A. 73: 1964-1968.

33. Itoh, N., T. Sei, K. Nose, and H. Okamoto. 1978. Glucose stimulation of the proinsulin synthesis in isolated pancreatic islets without increasing amount of proinsulin mRNA. FEBS (Fed. Eur. Biochem. Soc.) Lett. 93: 343-347.

34. Ullrich, A., J. Shine, J. Chirgwin, R. Pictet, E. Tischer, W. J. Rutter, and H. M. Goodman. 1977. Rat insulin genes: construction of plasmids containing the coding sequences. Science (Wash., D. C.). 196: 1313-1319.

35. Villa-Komaroff, L., A. Efstratiadis, S. Broome, P.
Lomedico, R. Tizard, S. P. Naber, W. L. Chick, and W. Gilbert. 1978. A bacterial clone synthesizing proinsulin. Proc. Natl. Acad. Sci. U. S. A. 75: 3727-3731.

36. Lomedico, P. T., and G. F. Saunders. 1977. Cell-free modulation of proinsulin synthesis. Science (Wash. D. C.). 198: $620-622$.

37. Waterlow, J. C., P. J. Garlick, and D. J. Millward. 1978. Protein Turnover in Mammalian Tissues and in the Whole Body. Elsevier/North Holland, Amsterdam. 697-746.

38. Munro, H. N., C. Hubert, and B. S. Baliga. 1975. Alcohol and Abnormal Protein Biosynthesis: biochemical and clinical. Rothschild, M. A., M. Oratz, and S. S. Schreiber, editors. Pergamon Press, New York 33-67.

39. McKnight, G. S., and R. D. Palmiter. 1979. Transcriptional regulation of the ovalbumin and conalbumin genes by steroid hormones in chick oviduct. J. Biol. Chem. 254: 9050-9058.

40. Deeley, R. G., J. I. Gordon, A. T. H. Burns, K. P. Mullinix, M. Bina-Stein, and R. F. Goldberger. 1977. Primary activation of the vitellogenin gene in the rooster. J. Biol. Chem. 252: 8310-8319.

41. Guyette, W. A., R. J. Matusik, and J. M. Rosen. 1979. Prolactin-mediated transcriptional and post-transcriptional control of casein gene expression. Cell. 17: 1013-1023.

42. McKnight, G. S., D. C. Lee, D. Hemmaplardh, C. A. Finch, and R. D. Palmiter. 1980. Transferrin gene expression: effects of nutritional iron deficiency. J. Biol. Chem. 255: 144- 147

43. Schimmel, M., and R. Utiger. 1977. Thyroidal and peripheral production of thyroid hormones. Ann. Intern. Med. 87: 760-768.

44. Kurtz, D., and P. Feigelson. 1977. Multihormonal induction of hepatic $\alpha 2_{\mathrm{u}}$-globulin mRNA as measured by hybridization to complementary DNA. Proc. Natl. Acad. Sci. U. S. A. 74: 4791-4795.

45. Young, D. A., Giddings, S., A. Swonger, G. Klurfeld, and M. Miller. 1971. Interrelationships among the effects of glucocorticoids on carbohydrate, adenine nucleotide, RNA, and protein metabolism in rat thymus cells. In Proceedings, Third International Congress on Hormonal Steroids. Excerpta Medica, Amsterdam. 843. 